\title{
Participatory Demonstration and Evaluation of Onion Varieties in Lume and Dugda Woredas, East Shewa Zone of Oromia Regional State, Ethiopia
}

\author{
Fistum Miruts* Gadissa Ejersa \\ Ethiopian Institute of Agricultural Research, Melkassa Agricultural Research Center
}

\begin{abstract}
Onion (Allium cepa L.) is one of the most important vegetable crops grown in Ethiopia as well as in the study area. The crop is produced as a cash crop and it is widely used to increase the taste of the different types of food. The research activity was carried out to show the performance of recently released onion varieties (Nafis and Nasik red) along with the check (Bombay red) with their recommended agronomic recommendations through on-farm demonstration and evaluation under farmers' management and resources. Dugda woreda and Lume Woreda were purposively selected based on their onion production potentials from east Shewa zone. From each Woreda randomly one kebele was selected, Shinbi-Gamo kebele from Dugda woreda and Shera-Gibandiba from Lume woreda. Twenty-four farmers were selected, twelve farmers per woreda, for hosting the demonstrations. All the data collected from the demonstration fields and farmers were analyzed through simple descriptive statistics and preference ranking tool. The mean yield obtained from the demonstration field for each variety were $167.72 \mathrm{qt} / \mathrm{ha}$ (Nafis), $161.56 \mathrm{qt} / \mathrm{ha}$ (Nasik red) and $149.8 \mathrm{qt} / \mathrm{ha}$ (Bombay red) in Dugda woreda. In Lume woreda, the mean yield of the varieties was $320.39 \mathrm{qt} / \mathrm{ha}$ (Nafis) $257.39 \mathrm{qt} / \mathrm{ha}$ (Nasik red) and $257.39 \mathrm{qt} / \mathrm{ha}$ (Bombay red). Nafis variety shows better yield performance than the other two varieties in both woredas. The farmer's preference, further showed that Nafis variety was the best one or superior to the others by its high yielding ability, bulb size, and market preference. Therefore, agricultural research and woreda offices of agriculture should take the lead to further popularize the selected varieties in their respective mandate areas to boost production and productivity of the onion. Keywords: Demonstration, East Shewa Zone, Evaluation, Onion
\end{abstract}

DOI: $10.7176 /$ JNSR/9-17-06

Publication date:September $30^{\text {th }} 2019$

\section{Introduction}

In Ethiopia, agriculture is the leading sector which contributes to nearly $36.7 \%$ of GDP. It also serves as the main source of food and generates $88.8 \%$ of the foreign exchange earnings. The production of vegetable crops is much less developed than the production of grain crops in the country. From the total cultivated area, a larger area (90\%) was covered by grain crops (cereals, pulses, and oilseeds). Vegetables took up about $1.46 \%$ of the area under all crops at the national level with $1.91 \%$ of the production of the total crops (CSA, 2018)

Onion is one of the most important vegetable crops cultivated in Ethiopia. The crop is produced as a cash crop and it is widely used to increase the taste of the different types of food. Onion is cultivated by smallholder farmers and commercial growers both under the irrigation and rain feed conditions where the larger area is covered under irrigation (Asfaw, 2015). East Shewa zone, the study area, has great potential for onion cultivation, due to the availability of sufficient irrigated farmland and the presence of relatively better market access as compared to the other areas (Teshome et al.,2015).

According to the central statistics agency (CSA 2018) report, the area covered by onion was around 31,673.21 hectares (ha) with a total production of 2,938,875.85 quintals (qt) in 2017/18. Comparing with the 2012/2013 cropping season, there was about $31 \%$ increment in area coverage and a $25 \%$ increment in production. However, the productivity of the crop is getting lower and lower year after year. Comparing 2012/13 cropping season productivity (100.24 qt/ha) with the 2017/18 cropping season $(92.79 \mathrm{qt} / \mathrm{ha}$ ) productivity, there was about $7.4 \mathrm{qt} / \mathrm{ha}$ yield difference (Table 1). Comparing the national average onion yield with the yield obtained at the research (400 $\mathrm{qt} / \mathrm{ha}$ ), there is about $300 \mathrm{qt} / \mathrm{ha}$ yield difference according (MoA, 2018).

This low yield results indicate that the presence of a huge gap in productivity. This is attributed to several constraints among which the absence of an authorized body that produces and distributes the improved onion seed varieties and the application of inappropriate agronomic practices are the major ones (Mahlet, 2012; Teshome et $a l ., 2015)$. Hence, with these in view, the study was carried out to show the performance of recently released onion varieties with their recommended agronomic recommendations (Nafis and Nasik red) and compare their performance with the one that farmers are using (Bombay red) through on-farm demonstrations and evaluation. 
Table 1: Area coverage, production and productivity of onion in Ethiopia

\begin{tabular}{|c|c|c|c|c|}
\hline Year & $\begin{array}{c}\text { Area } \\
\text { coverage (ha) }\end{array}$ & $\begin{array}{c}\text { Production } \\
\text { (qt) }\end{array}$ & $\begin{array}{c}\text { Productivity } \\
\text { (qt/ha) }\end{array}$ & $\begin{array}{c}\text { Yield (qt/ha) \% change from the } \\
\text { previous years }\end{array}$ \\
\hline $2012 / 13$ & $21,865.37$ & $2,191,886.02$ & 100.24 & -10.06 \\
\hline $2013 / 14$ & $24,375.70$ & $2,197,352.67$ & 90.15 & 12.4 \\
\hline $2014 / 15$ & $22,771.88$ & $2,307,451.89$ & 101.35 & -11.46 \\
\hline $2015 / 16$ & $29,517.01$ & $2,648,493.54$ & 89.73 & 8.6 \\
\hline $2016 / 17$ & $33,603.39$ & $3,274,752.45$ & 97.45 & -4.78 \\
\hline $2017 / 18$ & $31,673.21$ & $2,938,875.85$ & 92.79 & \\
\hline
\end{tabular}

Source: CSA (2012 - 2018)

\section{Materials and Methods}

\subsection{Description of the Study Area}

The study was conducted in Lume and Dugda woredas of East Shewa Zone, Oromia Regional State of Ethiopia. The altitude of the area ranges from 538 to 3101 meter above sea level with an average annual rainfall of 969.35 $\mathrm{mm}$ and annual temperature of $20.4{ }^{\circ} \mathrm{C}$. East Shewa zone is classified into slight, moderate and severe agricultural drought risk subzones covering $17.18 \%, 41.32 \%$ and $41.50 \%$ of the total area, respectively. The economy of the Zone is based on agriculture which is characterized by mixed farming and the rain-fed farm covers a large area (Legesse and Suryabhagavan 2014).

\subsubsection{Lume Woreda Description}

Lume woreda is located $25 \mathrm{~km}$ to the west of the regional capital, Adama. It is located between $8^{0} 12^{\prime}$ to $8^{0} 50^{\prime}$ latitude and between $39^{\circ} 01^{\prime}$ to $39^{0} 17^{\prime}$ longitude. The area has wide range of altitudes from 1500 to 2300 meter above sea level. The total area of the woreda is 65,130 hectares. The major soil type of the Woreda is vertosol and the monthly temperature ranges $22^{\circ} \mathrm{C}$ to $34^{\circ} \mathrm{C}$. The economy of the woreda is based on agriculture which is characterized by mixed farming. The major crops produced included, vegetables, cereals and pulses integrated with livestock production (Abrham, 2009).

\subsubsection{Dugda Woreda Description}

Dugda woreda is located $82 \mathrm{~km}$ to the west of the regional capital, Adama. It is located $8^{0} 01^{\prime}$ to $8^{0} 25^{\prime}$ latitude and $38^{0} 32^{\prime}$ to $39^{\circ} 04^{\prime}$ longitude. The area has an altitude of ranges from 1600 to 2020 meter above sea level. The total area of the woreda is 95,945 hectares. The two major types of soil in the woreda are Sandy Loam (59\%) and Clay Loam (41\%). the mean annual temperature and annual rainfall is $22^{\circ} \mathrm{c}$ to $28^{\circ} \mathrm{c}$ and 700 to $800 \mathrm{~mm}$ respectively. The major crops produced included, vegetables, cereals and pulses integrated with livestock production. Even though there are inadequate irrigation facilities, vegetable crops (onion, tomato, cabbage, green pea and chili) are largey planted and harvested two to three times in a year using Ziway Lake, Meki River and underground water as a source of water and characterized as traditional irrigation system (DWOA, 2018).

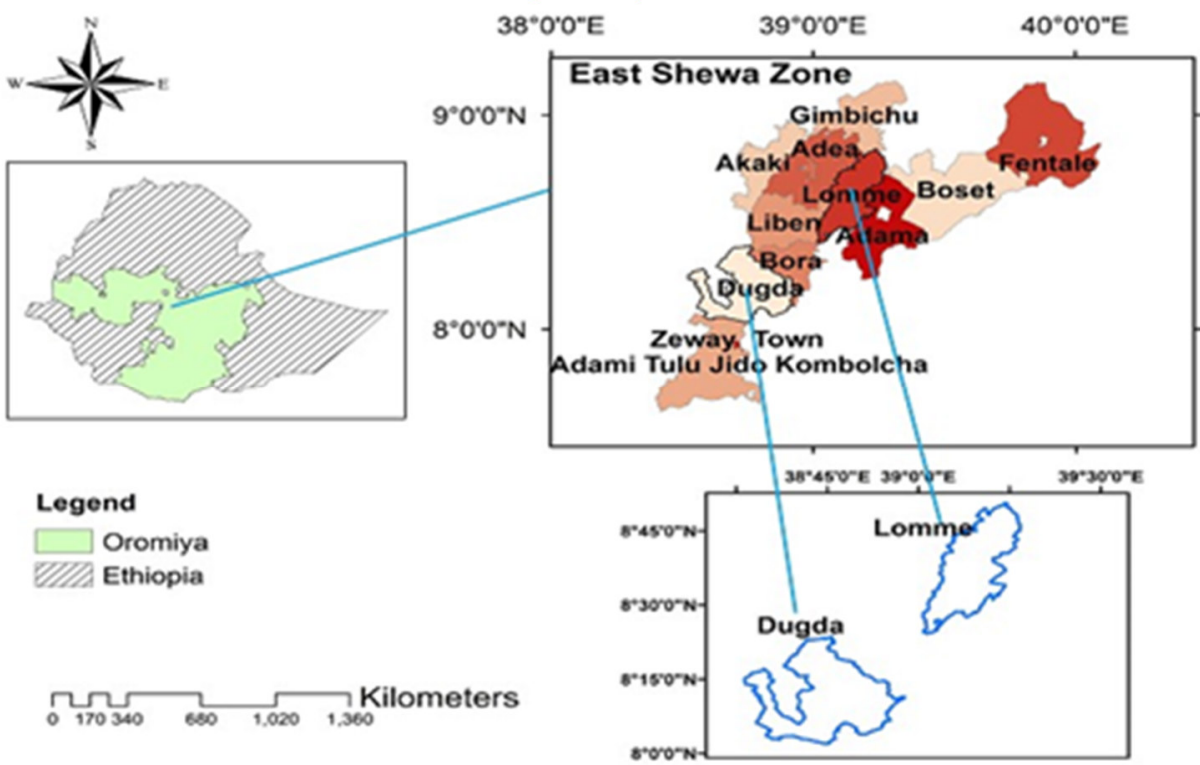

Figure 1: Location of the study area 


\subsection{Farmers Selection and Field Establishment}

For this activity, Dugda woreda and Lume woreda were purposively selected based on their onion production potentials from the east Shewa zone. From each woreda randomly one kebele was selected, Shubi-Gamo kebele from Dugda woreda and Shera-Dibendiba from Lume woreda.

In consultation with Woreda agricultural experts, farmers who have an interest in the technology, access to irrigation, willingness to manage and allocate field for the demonstration and willingness to collaborate with extension agents and researchers were selected for hosting the demonstration. Twenty-Four farmers (12 in ShubiGamo and 12 in Shera- Dibendiba) were selected and the demonstrations were established in a farmer's field where each farmer was considered as a replication. For the demonstration full technology packages of onion were provided and farmers prepared 0,25 ha. The varieties (Nasik red and Nafis) that have been released from the research were planted side by side to demonstrate and compare their performance with the one that farmers were using in the study area (Bombay red).

Before the establishment of the demonstration or planting the seeds, both practical and theoretical training was provided on the improved onion technology from production to marketing. The varieties were planted in 0.25 hectares in each demonstration host farmers' field and each farmer was considered as replication. In the demonstration plots, farmers planted the seedlings in $40 \mathrm{~cm}$ water furrows with $20 \mathrm{~cm}$ row on beds and $5 \mathrm{~cm}$ between plants. Fertilizer application, irrigation, insect pest control, and other necessary practices were applied including per the onion production package $(\mathrm{MoA}, 2018)$. The date of planting was maintained the same for all varieties. Follow-ups and essential advice from respective researchers and agricultural experts have been given to demonstration host farmers.

\subsection{Data Collection and Analysis}

Data were collected like yield by the researchers directly from the field. Perception data of the varieties were recorded from focus group discussion during the evaluation process. The collected data were analyzed using descriptive statistics and preference ranking based on farmers' set criteria.

\section{Result and Discussion}

\subsection{Yield Performance}

From demonstration plots, yield data were collected from a twenty-two farmers field. The mean yield performance of onion varieties in Dugda woreda was $149.8 \mathrm{qt} / \mathrm{ha}, 161.56 \mathrm{qt} / \mathrm{ha}, 167.72 \mathrm{qt} / \mathrm{ha}$ respectively for Bombay red, Nasik red and Nafis varieties. In Lume woreda, the mean yield was $269.22 \mathrm{qt} / \mathrm{ha}, 257.39 \mathrm{qt} / \mathrm{ha}, 320.39 \mathrm{qt} / \mathrm{ha}$ respectively for Bombay red, Nasik red and Nafis varieties. The onion demonstration yield result obtained was higher than what was reported as mean onion yield of the area by the central statistics agency (CSA) during 2018 and before. In the demonstration, increment in yield could be associated with proper follow-up and implementation of the technology package. Generally, in both locations, the productivity of Nafis variety is much higher than the other two varieties (MoA, 2018). Summarizing the yield result of the varieties from the two woredas, Nafis variety is productive than Nasik and Bombay red onion varieties.

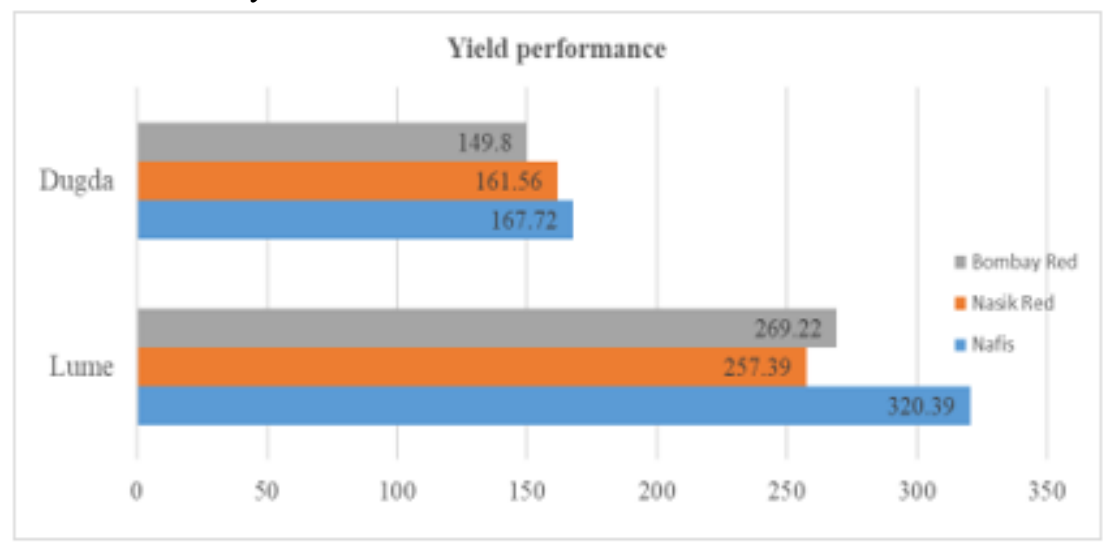

Figure 2:. Yield performance of onion varieties in the demonstration woredas

\subsection{Yield Increment and Advantage}

In the Lume woreda, the highest yield increment (51.2 qt/ha) was recorded by Nafis with a $16 \%$ yield advantage over the standard check (Bombay red). Similarly, in Dugda woreda, 17.9 qt/ha yield increment and 10.7\% yield advantage were recorded by Nafis compared with the standard check. Nasik red variety recorded higher yield increment in Dugda woreda with a 10.7\% yield advantage. Generally, the average yield gained from the demonstrated varieties has a $62 \%$ yield advantage over the farmer's average yield in the same production season. 
These show that if farmers follow the recommended practices, there is a chance to improve the productivity of onion at least by $57 \mathrm{qt} / \mathrm{ha}$ keeping the variety they used the same.

Table 2: Yield increment and advantage over the standard check in the demonstration

\begin{tabular}{|l|c|c|c|c|}
\hline \multirow{2}{*}{ Location } & \multicolumn{2}{|c|}{ Mean yield increment (qt/ha) } & \multicolumn{2}{c|}{ Mean yield (qt/ha) advantage (\%) } \\
\cline { 2 - 5 } & Nafis Varity & Nasik red Varity & Nafis Varity & Nasik red Varity \\
\hline Lume Woreda & 51.2 & -11.8 & 16 & -4.6 \\
\hline Dugda Woreda & 17.9 & 11.8 & 10.7 & 10.7 \\
\hline
\end{tabular}

\subsection{Farmers' Preference}

The demonstrated onion varieties were evaluated by farmers' set preference criteria in both locations by participating twenty-four onion grower farmers. The criteria used were the yield, bulb size, bulb color, storability, pungency and market preference. Accordingly, the color of the bulb and pungency for women farmers and market preference for men farmers were set as the very important among the criteria.

The ranking of onion varieties based on farmers' criteria indicated that in both woredas, farmers ranked Nafis variety as the most preferred onion variety compared to Nasik red and Bombay red varieties. Based on farmers' perception, Nafis variety was ranked first as it produces a good yield, bulb size and preference more at the market. Nasik red was the second most preferred variety in Dugda woreda. However, in Lume woreda Bombay red was preferred more than Nasik red variety (Table 3). Furthermore, the focus group discussants raised that, unavailability of improved seed and high cost of seeds of high yielding varieties are among the major constraints which hinder the onion production and productivity in the demonstration woredas, the same result was also reported by (Amsalu et al, 2014). Similarly, farmers reported that the major insect pest Trips and Fungus (Purple Bloch) identified as a major disease affecting onion production in the woreda.

Table 3: Farmers preference ranking of the Onion varieties

\begin{tabular}{|l|c|c|c|c|c|c|c|c|}
\hline \multicolumn{1}{|c|}{ Varieties and Rank (Lume Woreda) } \\
\hline Varieties & Market & Yield & Bulb color & Pungency & Bulb size & Storability & T. Score & Rank \\
\hline Nafis & 1 & 1 & 1 & 1 & 1 & 2 & 7 & 1 \\
\hline Nasik red & 3 & 2 & 2 & 3 & 3 & 3 & 16 & 3 \\
\hline Bombay red & 2 & 3 & 3 & 2 & 2 & 1 & 13 & 2 \\
\hline \multicolumn{8}{|c|}{ Varieties and Rank (Dugda Woreda) } \\
\hline Nafis & 1 & 1 & 2 & 2 & 1 & 2 & 9 & 1 \\
\hline Nasik red & 2 & 3 & 1 & 1 & 2 & 1 & 10 & 2 \\
\hline Bombay red & 3 & 2 & 3 & 3 & 3 & 3 & 17 & 3 \\
\hline
\end{tabular}

NB: preference ranking scale 1-3 (1= highest preferred and $3=$ lowest preferred)

\section{Conclusion and Recommendations}

From the findings of this research, it was observed that there was a difference among the varieties used for the demonstration in the study woredas. Hence, Nafis was found as the best onion variety as it produces a higher yield than Nasik red and Bombay red verities in both woredas. Similarly, farmers also show their preference to Nafis variety than Nasik red and Bombay red varieties based on the bulb size and preference at market places in addition to productivity. Bombay red variety preferred before Nasik red variety based on farmers preference in Lume woreda. However, in Dugda woreda Nasik red was preferred more than Bombay red by its bulb colour, pungency, storability and preferred more at market places. Thus, it can be concluded that Nafis is the best variety than the other two. Therefore, research and offices of agriculture should take the lead to further popularize the selected varieties in their respective mandate areas to boost production and productivity of onion. Besides, seed multiplier, offices of agriculture and research centers should involve in seed multiplication of the preferred varieties to improve the challenges and productivity of onion in the study woredas.

\section{Acknowledgement}

The financial support of the Ethiopian Institute of Agricultural Research, the effort of MARC staff as well as the woreda and Kebele agricultural experts during the course of action warmly recognized.

\section{References}

Abrham Feyissa. (2009). Grain market and rural livelihoods in Ethiopia: A case of structure, conduct and performance of grain market in Lume Woreda of Oromiya region.

Amsalu Ayana, Victor Afari-Sefa, Bezabih Emana, Fekadu F. Dinssa, Tesfaye Balemi, Milkessa Temesgen. (2014). Analysis of Vegetable Seed Systems and Implications for Vegetable Development in the Humid Tropics of Ethiopia. International Journal of Agriculture and Forestry, 4(4): 325-337. 
Asfaw Zeleke and Eshetu Derso (eds). (2015). Production and management of major vegetable Crops in Ethiopia. Volume 1, Addis Ababa, Ethiopia. Ethiopian Institute of Agricultural Research, Addis Ababa, Ethiopia; KOPIA Ethiopia Centre, Addis Ababa, Ethiopia. Printed at Eth-Cana Printing Press 149 pages Addis Ababa, Ethiopia.

CSA (Central Statistical Agency). (2018). Agricultural Sample Survey, Vol 1. Report on Area and Production of major crops, Meher season. Statistical Bulletin 586. Addis Ababa, Ethiopia.

CSA (Central Statistical Agency). (2017). Agricultural Sample Survey, Vol 1. Report on Area and Production of major crops, Meher season. Statistical Bulletin 585. Addis Ababa, Ethiopia.

CSA (Central Statistical Agency). (2016). Agricultural Sample Survey, Vol 1. Report on Area and Production of major crops, Meher season. Statistical Bulletin 584. Addis Ababa, Ethiopia.

CSA (Central Statistical Agency). (2015). Agricultural Sample Survey, Vol 1. Report on Area and Production of major crops, Meher season. Statistical Bulletin 583. Addis Ababa, Ethiopia.

CSA (Central Statistical Agency). (2014). Agricultural Sample Survey, Vol 1. Report on Area and Production of major crops, Meher season. Statistical Bulletin 582. Addis Ababa, Ethiopia.

CSA (Central Statistical Agency). (2013). Agricultural Sample Survey, Vol 1. Report on Area and Production of major crops, Meher season. Statistical Bulletin 581. Addis Ababa, Ethiopia.

DWAO (Dugda Woreda Agricultural Office). (2018). Summary of Agricultural activity achievements report.

Legesse Gizachew and K. V. Suryabhagavan. (2014). 'Remote Sensing and GIS Based Agricultural Drought Assessment in East Shewa Zone, Ethiopia'. Tropical Ecology 55(3): 349-63.

Mahilet, Yewendwesen. (2012). Adoption of Onion Production Package by Smallholder Farmers in the Dugda District in East Shoa Zone of Oromia Regional State, Ethiopia. Sl: sn.

Minstry of Agriculture (MoA). 2018. Horticultural crop packages, manual for agricultural extension experts. Amharic version, Addis Ababa, Ethiopia.

Teshome Abdissa, Feyissa Begna and Abnet Dereje. (2015). Pepper and Onion Yield Estimate Parameters as Affected by Seed Treatment Options: In the Selected Districts of Central Rift Valley; Oromia Regional State of Ethiopia. Open Access Library Journal, 2: e1243. http://dx.doi.org/10.4236/oalib.1101243. 